\title{
Ethnic Minorities and their Media in Sweden
}

\author{
An Overview of the Media Landscape \\ and State Minority Media Policy ${ }^{I}$
}

\author{
LEONOR CAMAUËr
}

In present-day Sweden, one person in twenty is a foreign citizen, one in ten was born outside the country and one in five has his or her background in other countries or cultures. As they go about their lives, these minorities - be they exiles, labour force immigrants or members of a diaspora or an indigenous population - uphold a simultaneous relationship to their present and former worlds, their homelands and places of current dwelling, and their in-groups and out-groups. The media, both the majority media and those that address these minorities as minorities, play a central role in this relationship. As media researcher Hamid Naficy (1999: 2) has observed, the media play a part that is both significant and signifying when it comes to creating, maintaining and even dissolving ethnic, national and post-national identities.

Minority media is used here as an overall concept for designing the media produced by, addressed to, and/or of especial interest for, ethnic minorities. According to Georgiou (2002), the only trait shared by these media is that they all address an audience imagining itself as a specific community and sharing a specific ethnicity. Minority media are otherwise marked by great diversity as they may be produced by commercial, community or public service actors, appear in the language of minorities, the language of the country of settlement, or a combination of both, be information-centred, entertainment-centred, or a combination of both, and have an output that relates to the country of origin, to the local, national or diasporic context, or to all of these.

Minority media constitutes an area that is quite poorly researched in Sweden, especially when it

Department of Humanities, Örebro University, SE70182 Örebroleonor.camauer@hum.oru.se comes to their conditions of production and status as objects of the state integration policy and cultural and media policies. This article constitutes a first (and rough) attempt to make an inventory of print and broadcast minority media in Sweden and their conditions of production, including the way in which they are affected by state policies. However, given the scantiness of time and resources at my disposal for its preparation, this mapping of (ethnic) minority media should be seen only as a work in progress.

In focusing on the production of minority media, I do not mean to imply that minorities should only be concerned with these media as regards either production or consumption. Both majority and minority media are vital components of (ethnic) minority groups' communication environment. In democratic societies, it is vital that citizens who are also members of a minority have their needs met by both kinds of media.

A fruitful way of theorising the relationship between majority and minority media can be found in the work of media researcher Charles Husband. He underlines that although it is necessary to have media operating within community languages and addressing the concerns of ethnic communities, media apartheid cannot be condoned. This is because a public sphere operating through parallel and exclusive communication systems cannot promote dialogue between fellow citizens. A truly permeable interface between mainstream media and ethnic minority media is therefore a basic requirement of multiethnic societies (Husband 1994: 2 \& 15).

This interface between minority and majority media could be realised in what Husband calls the multiethnic public sphere, which he defines as a public sphere that must reflect the currently existing eth- 
nic diversity in such a way as to facilitate the autonomous expression of ethnic identity of both minority and majority groups, as well as of national minorities. Moreover, this sphere must provide for the exchange of information and cultural products across these communities of identity. A central condition for the construction of such a multiethnic public sphere is the right to communicate, a right whose realisation places demands on the state: on the one hand, that it will abstain from arbitrarily interfering with individual's communicative freedoms, and on the other, that it will through its policies and actions ensure a material infrastructure of resources and institutions that will facilitate the exercising of these freedoms (Husband 2000: 207-10). Thus, the performance of states as regards these demands constitutes a measure of their willingness and ability to take public responsibility for the managing of ethnic diversity. This is why it is important and necessary to study the conditions of production of both majority and minority media, including state media and integration policies and systems of support.

The remainder of the article is structured as follows: I begin with an account of the method and materials used in the preparation of this inventory and continue with an overview of the minorities that currently live in the country. After this, I trace a brief history of migration from the Swedish perspective. I then enter the domain of policy, first sketching the main features of government policy on the treatment of immigrants and toward minorities from the 1960 s to the early 1990 s, then presenting the integration policy launched in the late 1990s. After this I give an account of the salient features of Swedish cultural policy and present in more detail the main institutions and instruments of media policy. This is followed by an inventory of minority media and a rough description of their conditions of production. I then present some views of those directly involved in the production of minority media, and my final comments.

\section{Compiling the Inventory}

When compiling this inventory, my main working method consisted of searching for and gathering catalogues and lists (e.g., of periodicals and community radio concession holders), programming schedules (e.g., those of the Swedish Television and the DTU7 channels), different organisations' declarations of principles, and official documents from governmental agencies. While many of the sources used were recent reports and documents, which guaranteed that they were up to date, I had, for in- stance, no possibility of checking whether all the periodicals in the National Integration Office's catalogue were still appearing. In this context it is also important to underline that it is virtually impossible to exactly assess the total amount of print and broadcast media at any given point in time, as the minority media landscape is continuously changing, with periodicals and community radio programmes constantly appearing and disappearing or becoming dormant. I therefore make no claim as to the completeness of this inventory.

The inventory of minority print publications is built mainly on the catalogue Invandrar- och minoritetstidskrifter (Immigrant and Minority Periodicals), which at the time I was preparing my report for the project Minorities and their Media in the EU: A Mapping (see Camauër 2002) was available at the web site of the National Integration Office. ${ }^{2}$ Other documents consulted include the list of recipients of grants to "art periodicals" provided by the Swedish Council for Cultural Affairs and the list of recipients of press subsidies provided by the Swedish Press Subsidies Council.

The inventory of minority radio programmes builds on a list of community radio (CR) concession holders provided by RTVV (the Swedish Radio and Television Authority), and on information available at the web site of the public service company Sveriges Radio, SR (Swedish Radio). ${ }^{3}$ The list of CR concession holders specified the name of the programmes, associations and contact persons, without explicitly indicating the language of the broadcasts. While in most of the cases the language was easy to deduce from the available data, I was unable to place some 50 concession holders in any language group, which led to their exclusion from this inventory.

To compile the inventory of television programmes I used information available at the web sites of the public service company Sveriges Television, SVT (Swedish Television), the public access channels Öppna Kanalen in Stockholm and Gothenburg, the commercial channel DTU7, the television programme Miniatyr and the cable operator com hem kabel tv. ${ }^{4}$

Reports published by RTVV and several official documents constituted valuable sources of information on broadcast media and government policy, and the report of a conference organised by minority media producers provided an insight on their analysis of their current situation.

To make the reading of this article easier for readers outside Sweden, I have given the subsidy amounts in $€$. 


\section{An Overview of Multicultural Sweden}

Sweden had slightly below 8.9 million inhabitants as of 31 December 2000. One million of these, or $11.3 \%$ of the population, were foreign-born (Befolkningsstatistik 2000, 2001). In comparison with other European countries, the Swedish population has a high percentage of foreign-born inhabitants (Integrationspolitik för 2000-talet, 2002: 10). However, these figures are insufficient to sketch the whole picture of a country that is growing ever more multicultural: they exclude a large number of people born and raised in the country of settlement, people who may still identify with the their parents' ethnic group. Statistics Sweden uses another category, people with for- eign background, which comprises foreign-born persons and persons born in Sweden with one or both parents born abroad, and therefore appears as more adequate an instrument for mapping diasporic communities. The number of persons with foreign background living in the country at the end of 2000 amounted to 1.8 million, or $20.5 \%$ of the population (Befolkningsstatistik 2000, 2001).

The table below shows the distribution of the Swedish population with foreign background according to continent/region, and some of the countries of origin.

The table shows that $14 \%$, or more than twothirds of the inhabitants with foreign background, come from European countries, while one-third

Table 1. Distribution of the Swedish Population with Foreign Background According to Continent/Region, and Some of the Countries of Origin

\begin{tabular}{lrc}
$\begin{array}{l}\text { Continent/region/ } \\
\text { country of origin }\end{array}$ & $\begin{array}{c}\text { Percentage of the total } \\
\text { population }\end{array}$ \\
\hline Nordic countries & 658.285 & 7.4 \\
Denmark & 95.883 & 1.1 \\
Finland & 447.450 & 5 \\
Norway & 112.340 & 1.3 \\
European Union & & \\
(Excluding Denmark and Finland) & 218.259 & 2.5 \\
Germany & 92.920 & 1 \\
Great Britain and Ireland & 29.724 & 0.3 \\
Europe & & \\
(Excluding the Nordic and EU-countries) & 364.559 & 4.1 \\
Bosnia-Herzegovina & 60.171 & 0.7 \\
Estonia & 26.012 & 0.3 \\
Hungary & 27.854 & 0.3 \\
Poland & 67.352 & 0.8 \\
Yugoslavia & 116.609 & 1.3 \\
Africa & 94.103 & 1.1 \\
Ethiopia & 19.093 & 0.2 \\
Somalia & 19.947 & 0.2 \\
North America & 51.162 & 0.6 \\
USA & 34.629 & 0.4 \\
South America & 77.345 & 0.9 \\
Chile & 41.662 & 0.5 \\
Asia & 371.594 & 4.2 \\
Iran & 67.864 & 0.8 \\
Iraq & 64.069 & 0.7 \\
Lebanon & 35.886 & 0.4 \\
Turkey & 60.026 & 0.7 \\
Oceania & 4.865 & 0.05 \\
\hline & & \\
& & \\
\hline
\end{tabular}

Note: The table is built on data from Befolkningsstatistik 2000 (2001). 
comes from other continents. Among the latter, Asia is the most strongly represented $(4.2 \%$ of the Swedish population), while the population groups originating from Africa, North America, South America and Oceania are considerably smaller.

A large majority of the immigrant population lives in the large urban areas of Stockholm, Gothenburg and Malmö, and the number of women and men comprised by this population is approximately the same (Integrationspolitik för 2000-talet, 2002: 10 and Rapport Integration 2001, 2001: 11). According to a recent report published by the National Integration Office, the life situation of a large part of the immigrant population is still characterised by low participation in elections, segregated living, high unemployment, dependency on public assistance and low income. However, there are some indications that the immigrant population's rate of participation in the workforce has become higher in the past few years (Working Together for Diversity, undated: 8 and 15).

\section{National Minorities}

Although the Sami constitute the only indigenous Swedish minority according to the UN definition, ${ }^{5}$ five groups are today regarded as "national minorities" for policy purposes: the Sami, Tornedal Finns, Swedish Finns, Roma/Gypsies and Jews. ${ }^{6}$ The Sami people have inhabited the northern portions of Scandinavia, Finland and eastward over the Russian Kola Peninsula since ancient times. Today, the Sami population of Sweden is estimated at 17,000-20,000 and many have merged with the majority population (The Sami People in Sweden, 1999). Approximately 25,000 Tornedal Finns today live in the valley of the Torne, the Muonio and the Könkämä rivers in northern Sweden. ${ }^{7}$ Swedish Finns are described as persons who live in Sweden, have Finnish as their mother tongue, were born in Sweden or Finland and, irrespective of their citizenship, identify themselves with the Swedish Finnish ethnic minority. As Swedish statistics do not register the language of individuals, it is difficult to assess the size of this minority group. ${ }^{8}$ While there is some proof that Roma/Gypsy people lived in Sweden as early as in the $16^{\text {th }}$ century, there is no evidence of a historical continuity. In 1999, the size of the group of Roma/Gypsies living in Sweden was estimated at 20,000-25,000. ${ }^{9}$ Finally, the number of Jews living in Sweden was estimated at approximately 20,000 in $1995 .{ }^{10}$ All these minority groups have formed organisations and produce their own media.

\section{A Brief History of Migration}

Like other European countries, Sweden had some exchange of population with other countries in the pre-industrial period (see Daun, 1992; Lundh \& Ohlsson, 1999/94 and Svanberg \& Tydén 1992 for accounts of early immigration to Sweden). However, the significance of the immigration in the period from the Middle Ages to World War II should not be overestimated: its volume was not high in quantitative terms (Lundh \& Ohlsson, 1999/94: 11). ${ }^{11}$ Since the mid- $19^{\text {th }}$ century, Sweden has had two periods with totally different patterns of migration. Whereas emigration outweighed immigration until the 1930 s, this pattern was reversed during the 1930s (Lundh \& Ohlsson 1999/94: 11).

The emigration of Swedes to America during the period 1840-1930 constitutes the only population movement comparable to the large (past or present) migration streams of other countries. It has been estimated that 1.2 million individuals, i.e. approximately $23 \%$ of the Swedish population in 1900 , left the country during that period (Daun, 1992: 8-9; Hultén, 2001: 276; Lundh \& Ohlsson, 1999/94: 11). While the bulk of this stream went to the USA, some Swedes migrated to Canada and nearby countries such as Denmark and Germany (Runblom, 1990: 35). The emigration of this period saved Sweden from the catastrophe of starvation in the $19^{\text {th }}$ century and simultaneously contributed to a population growth that enabled American economic success (Daun, 1992: 9).

The Swedish history of immigration in the $20^{\text {th }}$ century has been marked by a series of turns as regards the volume of migration and the government's and public opinion's attitudes toward immigrants. One of these turns occurred in the years around 1930, when the volume of migration quickly shrank. One of the reasons for this was the government's increasing unwillingness to receive refugees from other European countries. Above all, Sweden wanted to stop the European Jews who escaped from Germany and other territories controlled by the Nazi regime. A new turn in the government's immigration policy occurred in the last phase of World War II when Sweden, which until then had conducted what historian Harald Runblom (1990: 36) calls "an indulgent policy of neutrality" toward Germany, gave shelter to many Jews from Denmark. Runblom interprets this turn in government policy as a token of loyalty to the countries that were about to win the world. The stream of refugees received in Sweden between 1944 
and 1946 was considerably larger than the one at the end of the 1980s (Runblom, 1990: 35-36).

The willingness to support people from these countries must also be understood in the context of the nordism that had developed during the war. In the years after the war, the Swedish government's efforts in creating a Nordic political and economic region resulted in the development of the Nordic Council as a body of co-operation. One result of this co-operation was the establishment of a common Nordic labour market in 1954, which created the instrument that would regulate the part of the immigration to Sweden that had been the largest after the war, that from neighbouring countries. Thus was also solved part of the country's labour power problem (Runblom, 1990: 36).

In general terms, the immigration to Sweden from the end of the war to today has comprised three groups: labour force immigration from the Nordic countries and other Western-European countries, refugees from Eastern Europe and the Third World, and relatives of immigrants and refugees who had already been granted the right to stay in Sweden. In all, 2 million people migrated to Sweden after World War II (Lundh \& Ohlsson, 1999/94: 11). On the other hand, 1.2 million emigrated during the same period, which results in an immigration net balance of 800,000 . Of the total of foreign-born persons living in Sweden today, one-third are labour force immigrants, one-third refugees and one-third relatives of the two former groups (Integrationspolitik för 2000-talet, 2002: 9-10).

The government's immigration policy was liberal between the end the war and 1967, and foreigners could arrive in the country as tourists, find work and obtain a residence permit. In 1967 the immigration policy became more restrictive in one respect: New regulations were introduced, establishing that non-Nordic citizens must have residence and work permits before coming to Sweden and that these permits would be granted only after consultation with the National Labour Market Board. Due to the weak economic development since the mid-1970s, the new regulation made it considerably more difficult for non-Nordic workers to obtain permits. In another respect, however, the Swedish immigration policy has become even more liberal: refugees have been excepted from this regulation (Lundh \& Ohlsson, 1999/94: 11). Thus, the labour force immigration from non-Nordic countries virtually ceased in the early 1970 s, while streams of refugees from different countries have continued to arrive in Sweden.
The largest single national groups among the labour force immigration coming to Sweden between the end of the war and 1970 include: Finns, Norwegians, Danes, former West-Germans, Austrians, Italians, former Yugoslavians, Greeks and Turks (Integrationspolitik för 2000-talet, 2002: 9; Lundh \& Ohlsson, 1999/94: 30-32).

From the mid-1940s to the 1970s, most refugees were World War II refugees and dissidents from the communist block. The make-up of refugee immigration changed considerably in the mid-1970s, though, when other wars and domestic conflicts brought to Sweden refugees from countries such as Poland, Rumania, the former Yugoslavia, Yugoslavia, BosniaHerzegovina, Greece, Chile, Argentina, Peru, Uruguay, El Salvador, Kenya, Morocco, Ethiopia, Eritrea, Somalia, Turkey, Vietnam, Iran, Iraq, Lebanon and Syria.

The government's immigration policy was clearly connected to the economic growth. In periods characterised by a high growth rate, such as the years before 1914 and the period 1945-1970, the policy was liberal, while low-growth phases, such as the interwar period and the years between 1970 and 1998, were characterised by a restrictive policy (Lundh \& Ohlsson, 1999/94: 13-14). A similar point is made by Runblom (1990: 36), who underlines the important part played by the needs of the industrial sector in fuelling an active recruitment of labour force in other countries at the end of the 1940s. This liberal policy was conducted in full agreement between the national authorities and the enterprises, and immigration became a part of the Swedish labour market policy.

Several different areas can be distinguished in the Swedish policy for regulating immigration issues. The immigration policy comprises the principles and rules for deciding who will be granted the right to stay in the country. The policy on the treatment of immigrants refers to the provisions aiming at facilitating immigrants' introduction to and integration into their new society. The asylum policy includes the measures adopted to support persons who have been forced to flee from their country. The minority policy comprises the steps aiming to make it possible for minorities (those coming from other countries as well as the indigenous ones) to keep their linguistic and cultural particularities (Lundh \& Ohlsson, 1999/94: 54). Some aspects of the Swedish immigration policy have been touched upon in this section. Next, I turn to the government's policy on the treatment of immigrants and minority policy, and the replacement of the former in the late 1990s by the "integration policy". 


\section{From the Policy on}

the Treatment of Immigrants and Minority Policy to Integration Policy

In the second half of the $20^{\text {th }}$ century, Sweden instituted a comprehensive policy on the treatment of immigrants and minority policy. According to Lundh and Ohlsson (1999/94), Sweden lacked an articulate minority policy until the mid-1970s. Before this time, the policies toward ethnic minorities were disparate and aimed at assimilating them into the dominant culture of the country. In the beginning of the 1960s, both the indigenous minorities and the growing immigrant minorities started demanding support for the preservation of their cultures. A commission of inquiry was appointed in 1968 and presented its report in 1974. The Canadian minority legislation and the ideas of ethnic movements in different parts of the world influenced the report, which rejected assimilation policies and adopted a cultural pluralistic approach. The report concluded that the state should not force individuals to abandon their language and culture, and emphasised that the interplay between the majority and minority cultures would enrich society as a whole. This report gave Sweden its specific and rather unique minority policy (Lundh \& Ohlsson, 1999/94: 108ff).

The report proposed three overall goals for the state's minority policy: equality, freedom of choice and co-operation. The equality goal implied that the immigrant groups should have the same conditions of life as did the majority, not merely with regard to material standard but also with respect to their opportunities to become integrated in society. Moreover, immigrants and their children should have real possibilities of maintaining their language, culture and contact with their homeland. By freedom of choice it was meant that individual members of minority groups should be able to decide themselves the extent to which they wanted to hold on to their linguistic and cultural identities. The co-operation goal referred to the majority and minorities' joint action, which should be based on mutual tolerance and solidarity. The Parliament adopted these goals in 1975 (Lundh \& Ohlsson, 1999/94: 109). In this context it is also worth noting that Sweden has never had a "guest worker policy". Instead, all foreign workers have been offered permanent status, if they wished to stay in the country. One of the main reasons for this policy of permanent immigration has been the fact that Nordic labour immigration has dominated (Hammar, 1992: 17).

Since the mid-1960s, a large number of reforms have been carried out to improve immigrants' condi- tions of life and participation in society. A largescale programme of free Swedish language instruction was started in 1965, a government subsidised newspaper for immigrants began publication in 1967, a bill providing for special tuition in Swedish and other subjects for immigrant school children was adopted by Parliament in 1968, and a new government agency, the Swedish Immigration Board (Statens Invandrarverk), was established in 1969. A new law was passed, giving all aliens who have been resident in Sweden for at least three years the right to vote and run for office in local and regional elections. This law came into effect with the 1976 election. Further, in 1986 laws against discrimination were passed and an Ombudsman against Ethnic Discrimination appointed (Immigrants in Sweden, 1999).

The changed political and economic situation of the 1990s and criticism of the policy on the treatment of immigrants led to the appointment of a new commission of inquiry, which presented its report in 1996. After this, a Government Bill entitled Sverige, framtiden och mångfalden - från invandrarpolitik till integrationspolitik (Sweden, the Future and Diversity - From the policy on the treatment of immigrants to the integration policy; my translation) was sent to, and adopted by, Parliament. The Bill signalled a new orientation in the government's policy toward minorities and stated that the ethnic and cultural diversity of the country should be the starting point of the state's overall politics and its realisation in all areas and levels of society. According to the Bill, the measures directed to immigrants as a group should be confined to provisions solely concerning the immigrants' first years in the country, and their aim should be their integration (Sverige, framtiden och mangfalden ..., 1997). The aim of the new policy is to support individuals in order that they may be able to support themselves and participate in society, to safeguard basic democratic values and work for equality between women and men, and to prevent and counteract discrimination and racism (Integrationspolitik för 2000-talet, 2002: 6f).

In a recent official document it is argued that the policy on the treatment of immigrants adopted in 1975 made immigrants as a group visible in society and furthered an understanding of their needs, but at the same time singled out immigrants as a homogeneous group, and stressed their immigrant status and thereby their otherness. The former policy on the treatment of immigrants thus came to reinforce "us-and-them" feelings and contributed to the alienation that many immigrants and their children ex- 
perience today (Integrationspolitik för 2000-talet, 2002: 7).

According to Lundh and Ohlsson, the report from 1996 reflected the more liberal and market-oriented ideological climate of the decade, though without wholly breaking the main lines of the former policy. While the three earlier goals (equality, freedom of choice and co-operation) were maintained, the report stressed immigrants' own responsibility for their situation (Lundh and Ohlsson 1999/94: 120). The emphasis of the new policy on immigrants' financial self-sufficiency and ability to support themselves, seen as one of the standard measures of social integration, is thus not surprising in the context of the changed ideological streams of the 1990s.

To move away from a view of immigrants as a group, and to help implement more general measures in the social policy field, the government established a new agency in 1998, the National Integration Office (Integrationsverket), which has taken over the general responsibility for integration affairs from the Swedish Immigration Board (Immigrants in Sweden, 1999).

\section{Policies Affecting Ethnic Minority Media}

Regulations and provisions directly or indirectly affecting ethnic minorities and their media are chiefly found in two broad areas of public responsibility: the sphere of integration and the sphere of culture and the media.

\section{The Sphere of Integration}

As already noted, the policy on the treatment of immigrants and the minority policy conducted until the mid-1990s comprised a series of provisions aimed at immigrants as immigrants. According to the analysis made in a recent official document, this policy resulted in an emphasis on the immigrant status and the otherness of ethnic minorities (Integrationspolitik för 2000-talet, 2002: 7). In contrast, the new policy adopted in the second half of the 1990s emphasises integration. It is difficult to assess whether or not this policy shift is positive for ethnic minorities.

On the one hand, it can be said that many formulations of the new integration policy evoke theoretical gains from recent research in the areas of cultural theory, ethnicity and identity, and militate against essentialist conceptions of ethnic and cultural identity. On the other hand, the new integration policy will have negative practical conse- quences for specific ethnic communities. As a consequence of the adoption of this policy, a new system for regulating the state subsidies distributed by the National Integration Office came into force in 2001. The new system is clearly result-oriented and stipulates that the state give subsidies to organisations built on ethnic grounds as well as to other organisations. For both, a central condition for qualifying for the subsidies is that their activities be oriented to achieving the goals of the new integration policy. A recent official document discusses the way in which the new system of subsidies will affect organisations built on ethnic grounds, particularly those formed many years ago that organise people from countries from which there is no immigration today. The document notes that these organisations have little reason to conduct integrationoriented work and that they instead prioritise activities aiming at maintaining their members' cultural identity, language and bond to the homeland, e.g. the publication of newspapers or magazines. Thus, even though the new system of state subsidies still provides some support for this kind of activity, it will result in reduced allocations for these "old" organisations. For support for their "identity work", the latter organisations are expected to turn to other instruments of the general social and cultural policy, e.g. the provisions available to all voluntary associations in the country (see Integrationspolitik för 2000-talet, 2002: 69-73).

\section{The Sphere of Culture and the Media}

The new cultural policy goals sanctioned by Parliament in 1996 are inspired by a "world culture-perspective" and apply to all areas within the state, municipalities and counties (Integrationspolitik för 2000-talet, 2002: 79). One of these goals is to "promote international cultural exchange and meetings between different cultures on the domestic front" (Swedish Cultural Policy: A Brief Review... 1997: 13). In practice, the State, county councils and municipalities share the responsibility for public support of cultural life. The central cultural institutions and nationwide activities receive government funding. Parliament decides on the total volume of grants, and the funds are then distributed by the Ministry of Culture and public agencies within the cultural sphere. The four units of the Ministry of Culture deal, respectively, with cultural heritage, art forms, the media, and co-ordination, development and finances. The National Council for Cultural Affairs (Statens kulturråd) is the government agency that bears the principal responsibility for national cultural 
policy (Swedish Cultural Policy 1998; Swedish Cultural Policy: A Brief Review... 1997: 42).

The goals and range of activities of national cultural institutions have been gradually extended during the past years, and in the directives for 2002 it is stated that their goal is on the one hand to promote social and gender equality, respect and tolerance, and a view of ethnic, cultural, linguistic and religious diversity as positive forces, and on the other hand to contribute to reducing discrimination and racism (Integrationspolitik för 2000-talet, 2002: 79).

Let us now turn to the specific domain of media policy. The overall goal of the Swedish media policy, as stated in the Budget Proposals for 2001/ 02 , is to support the freedom of expression, diversity, and the independence and accessibility of the mass media, and to counteract harmful content in the mass media (Budgetpropositionen, Prop. 2001/ $02: 1$, p. 112). According to the Ministry of Culture, there is neither any all-encompassing document describing the Swedish media policy nor any document describing the state overall policy on minority media. ${ }^{12}$ Two official documents recognise that the government lacks an overall view of the media that address immigrants and minorities. In order to remedy this, the Press Subsidies Council was commissioned in 2001 to map and analyse the situation of the media chiefly directed to immigrants and national minorities in Sweden (Budgetpropositionen, Prop. 2001/02:1, p. 113; Integrationspolitik för 2000-talet, 2002: 82). The investigation report was presented in the fall of $2002 .{ }^{13}$ The instruction of the commission did not comprise the presentation of proposals for measures or changes. Among other things, the report concluded that:

- minority media play an important role in minorities' well-being and integration,

- Sweden lacks a system of state support for $r a$ dio and $T V$ in minority languages (emphasis added),

- Sweden is now the only Nordic country that lacks specific forms of support for minority media production (emphasis added),

- immigrants are under-represented in schools of journalism,

- there is a lack of further education \& training for minority media workers, and

- minority media needs increased support, not just economic, but also as regards co-ordination, development and training (e.g., in the domain of marketing $\&$ advertising promotion).
Eight months after the presentation of the report, no specific follow-up or further policy preparations were reported by the Ministry of Culture. ${ }^{14}$ However, some indications have come from other quarters, concerning the launching of a new Commission of Inquiry on the Press, where the results of the mentioned report could be included in the discussions.

According to media scholars Stig Hadenius and Lennart Weibull, the Swedish media policy is characterised by a combination of: a) state intervention in the structure and organisation of the media (e.g., market regulations and support to newspapers in order to safeguard the diversity of the daily newspaper market); b) steering through norms and rules for media content such as rules of impartiality and objectivity for radio and television, and conditions for granting broadcasting concessions; and c) allowing the market to function as a steering instrument (Hadenius \& Weibull 1999: 33f). One could thus say that the overall media policy combines elements from the free-market and the social-responsibility ideologies.

Several public institutions are involved in the management of policies toward immigrants and minorities. In the following I briefly account for the main institutions and instruments of the policies that directly or indirectly concern the media produced by and/or addressed to immigrants and minorities and shape their form and function.

\section{Literature and Public Libraries}

Literature and libraries constitute an important cultural area from the point of view of ethnic minorities. The government supports the publication of literature in minority languages as well as the Printon-demand project Podium, which further stimulates the publication of books in these languages. The system of publishing grants was modified in 1999 in order to include new immigrant groups (Integrationspolitik för 2000-talet, 2002: 81). Although few of the ethnic communities exercise much influence in Sweden, some are important internationally: thanks to official support, Kurds working in Sweden, for instance, have made the country a major centre for Kurdish-language publishing (Swedish Cultural Policy: A Brief Review... 1997: 39).

Responsibility for the approximately 1,600 public libraries rests with the municipalities, but the state undertakes to support the nationally coordinated library system through grants. The government subsidises, for instance, a central service 
for inter-library borrowing of books in minority languages, which is available to all public libraries. Libraries in municipalities with many inhabitants of foreign background have adapted their offer to the needs of their users. According to a study from 2000 , foreign citizens constitute the group who visits libraries most often (Integrationspolitik för 2000-talet, 2002: 81; Swedish Cultural Policy 1998; Swedish Cultural Policy: A Brief Review... 1997: 39).

\section{Newspapers and Periodical Publications}

This section accounts for three main instruments of the policies affecting the newspapers and periodical publications directed to and/or produced by minorities: the press subsidies, the grants to "arts periodicals", and the organisation subsidies distributed by the National Integration Office.

The origin of the press subsidies is found in the government's concern for upholding diversity within the newspaper market. The number of newspapers declined sharply in Sweden during the post-war era, from 216 in 1945 to 162 in 1998 . In order to counteract further concentration of ownership, the government created a system of press subsidies, which is managed by the Swedish Press Subsidies Council (Hadenius \& Weibull 1999). To qualify for the subsidies a newspaper should be issued at least once a week and be distributed mainly in Sweden as well as written in Swedish. However, newspapers in other languages are also entitled to the subsidies if they address linguistic minorities, have their main editorial office in Sweden, distribute at least $90 \%$ of the subscribed circulation in Sweden, and have a circulation of at least 2,000 copies (Statute of Annual Press Subsidies, SFS 1996: 1607, p. 1-3; Mass Media, 1999).

The Swedish Council for Cultural Affairs annually allocates government grants to "arts periodicals", by which is meant periodicals "whose main contents are directed to the general public, providing social information, or economic, social or cultural debate, or which mainly give space to analysis and presentation within the various areas of the arts" (www.kur.se 2002-05-31). Since 1999, the Council is commissioned to give special support to periodicals in national minority languages.

The National Integration Office distributes the state subsidies to organisations built on ethnic grounds and other organisations working with integration issues. Two of the allocations, the Organisation Subsidy and the Activity Subsidy, are directed toward ethnic minority associations. The first aims at covering part of the organisations' costs for administration, premises, IT support and information spreading, whereas the second is intended to support integration-oriented activities. ${ }^{15}$

To be sure, the subsidies mentioned above constitute only a part of the support that is, at least in principle, available and that can be sought by minority media producers from a range of state, regional and municipal administrations, foundations and cultural institutions. On the other hand, budget cuts in the public sector during the past decade have made it considerably more difficult to obtain funding.

\section{Broadcast Media}

To understand the state policy toward minority broadcast media it is necessary to bear in mind some recent developments in Swedish media history. Radio and television have undergone considerable changes since the late 1980 s. The former public monopoly on radio and television broadcasting is now giving way to a new media landscape in which public service companies operate side-by-side with commercial radio and television channels and cable operators, community radio stations and non-profit local television stations. The licences for broadcasting television and radio programmes are granted by the government through Radio- och TV-verket, RTVV (the Radio and Television Authority). The licensing conditions for the five-year concession period starting in 2002 instruct the public service corporations Sveriges Radio, SR (Swedish Radio) and Sveriges Television, SVT (Swedish Television) to continue and deepen their efforts to cater to the needs of national minorities and other linguistic and ethnic groups (Budgetpropositionen, Prop. 2001/02: 1, p. 113). ${ }^{16}$

\section{Radio}

At the end of the 1970s, voluntary associations were allowed to broadcast within limited geographical areas, which marked the start of Swedish community radio (CR). Advertising was, however, banned from these broadcasts. After a test period, a permanent CR system was implemented in 1986 , aimed at providing associations and organisations with a channel of information. The programmes must be locally produced, and the reach of the CR stations is limited to a range of five $\mathrm{km}$ from the sender, although wider ranges are allowed in some cases. CR programming is not subject to the rules of objectivity (Cultural Policy, 1998; Mass Media, 1999; Hadenius \& Weibull 1999: 176-9 \& 264). When it comes to funding for the system, the CR 
concession holders were expected to bear the costs and no state subsidies were provided for the operation of CR (Närradio... 2002: 17). On the other hand, no fee must be paid for the concession today.

In 1993 it became possible to operate privately financed local radio, and, at the same time, advertising and sponsorship of CR programmes was allowed (Swedish Cultural Policy, 1998). Despite the appearance of these two new actors, CR and local commercial radio, the licence-financed public service Swedish Radio still plays a central role both in the media system as a whole and as regards the production of programmes addressed to minorities.

\section{Television}

It was the introduction of satellite-borne commercial television in the second half of the 1980s that paved the way for a profound change in the Swedish broadcasting system. The 1987 launching of TV3, a Scandinavian satellite channel broadcasting from London, marked the introduction of commercial television in Sweden. After this, resistance to commercially financed, terrestrial television broadcasting in Sweden collapsed. TV4, a commercial terrestrial channel with nationwide coverage, was launched in 1992. The channel pays a concession fee to the state and is subject to certain public service obligations. The expansion of the cable network for the distribution of television programmes sent via satellite radically altered the Swedish media market at the end of the 1980s. The legislation on cable broadcasting that came into force in 1992 paved the way for the distribution of satellite transmissions by cable; now, any individual is at liberty to transmit television programmes in this way. Cable transmissions of this kind may be financed with advertising revenue and are subject to certain rules concerning content and volume of advertising. The cable networks also distribute their own programmes. These are of two types, either mainly non-profit local television stations or commercial broadcasting companies (Cultural Policy, 1998; Mass Media, 1999). According to the current legislation, each operator of a cable network reaching over 100 households must put one channel at the disposal of a local, non-profit cable channel appointed by the Radio and Television Authority. The appointed cable channels distribute their programmes without paying a fee to the cable operators. These channels, usually called community or public-access TV, are intended to function as a forum in which all citizens may make their voice heard and to provide less powerful actors with access to the television medium (Bakgrundsmaterial... 2002: 5 \& 8).
The Charter for Television Broadcasting Services in Sweden, in which the general policy of the public service corporation SVT is laid, instructs SVT to mirror the multicultural character of contemporary Sweden as well as the cultural life of other countries. The document also underlines the responsibility of the company to take the needs of linguistic and ethnic minorities into account, with particular attention to the Sami, Finnish and Tornedal-Finnish cultural spheres. The linguistic needs of children in cultural and ethnic minority communities are also to be taken into account by SVT. ${ }^{17}$

\section{Minority Media in Sweden A Preliminary Inventory}

In this section I present a summary of the inventory of print and broadcast minority media produced in Sweden in 2002. ${ }^{18}$ The most important findings are first summarized in Table 2 and then discussed in more detail in the three subsections dealing with minority press, minority radio and minority television, respectively.

\section{Minority Press}

My inventory of minority periodicals comprises 181 titles in 37 minority languages, Swedish and English. This figure is rather close to that given in other recent sources. ${ }^{19}$ Approximately 40 of these publications are in two or more languages, the most common combination being Swedish and one minority language (25 titles). In many cases, the reason for publishing in Swedish is that the associations want their periodicals to be read by the majority society; they want to convey information about their countries and continents in order to facilitate a twoway communication (Invandrar-och minoritetsmedia i Sverige... 2000: 52, 56-7 \& 64).

The minority languages represented with the most titles are: Finnish (38), Arabic (16), Kurdish, Persian and Spanish (14 titles each), and Turkish and Estonian ( 7 titles each). Of the 57 titles published in Swedish, 27 combine this language with one or more other languages, the most common being Arabic, English, Aramaic, Turkish and Spanish. The 30 titles in Swedish alone comprise the publications by minority groups wishing to reach a broader readership and periodicals edited by majority society institutions and organisations that deal with issues of especial interest for minority groups. Ten periodicals are in English, seven of which are in English and one or more other languages. If one is to judge from the title 
of the periodicals and the affiliation of the editors, none seems to be the publication of an Englishspeaking minority. For this reason, English seems to be used here as a sort of lingua franca.

When comparing the distribution of titles according to minority languages with the size of the ethnic minority groups living in the country, one can see that in most cases there is a direct relation between the size of the groups and the number of periodicals. There are, however, exceptions such as the Danish, German and Norwegian groups, which are rather large (1-1.3\% of the total population) but have only one or two publications, and the Estonians, who constitute a relatively small group $(0.3 \%$ of the total population) but have seven publications.

Unfortunately, the available data on the periodicals does not allow for an accurate assessment of the periodicity of the publications. The catalogue I consulted gave this kind of data for only 115 , or approximately $63 \%$, of the 181 periodicals.

On the whole, it can be said that the minority press landscape is populated by many unpaid enthusiasts who produce a great number of small, low periodicity (4-6 issues per year) publications, which often have financing problems. There are, however, five weeklies that address ethnic minorities, four of which are published in minority languages: Eesti Päeväleth (Estonian), Liberación (Spanish), and Ruotsin Suomalainen and Viikkoviesti (Finnish). The two former are small and struggle to keep their circulation above the 2,000-copy limit (which is a condition for receiving the press subsidy). The fifth newspaper, Nyhetstidningen Sesam, is published in Swedish and, in contrast to the former, does not address a specific minority but all immigrants and minorities living in Sweden. According to its former editor this can be seen as a problem, but also as an advantage in that it widens the scope of the readership and caters to the needs of second-generation immigrants. Many children of immigrants find it difficult to read in their parents' mother tongue and want to read about their own multicultural reality (Boldt 2001: 4 \& 8).

The issue of funding is central to the survival of the periodicals and many of them cease publication after a few years due to lack of money. Miguel Benito, head of the documentation centre Immigrantinstitutet, has made a cogent distinction between three kinds of publications. According to Benito, some minority periodicals function as member bulletins and production costs are covered by members' fees. Others, mainly Finnish publications, are clearly local. There have been more than 100 such periodicals, which were usually funded by municipalities, unions or the Social-Democratic
Party and managed to attract some local advertising. A third group comprises periodicals that are distributed across the whole country. It is this third category that faces the most economic problems, as many of these publications find it difficult to attract nationwide advertising (Invandrar- och minoritetsmedia I Sverige... 2000: 6 \& 77-9).

In 2002 the "direct press subsidies" (i.e., the operational subsidy and the distribution subsidy) totalled approximately 57.2 million $€,{ }^{20}$ approximately 1.3 million $€$ of which went to the five weeklies mentioned above. Nyhetstidningen Sesam, which had 13,000 subscribers, received $400,000 €$, while the remaining four were granted $222,000 €$ each. ${ }^{21}$ The indirect press subsidies consist of tax exemptions.

The appropriation for the grants to "arts periodicals" distributed by the Swedish Council for Cultural Affairs amounted to about 2.3 million $€$ in 2001. In 2002, grants were allocated to 126 periodicals, of which a fifth, or 25 publications, were produced in languages other than Swedish. Of the latter, 23 addressed ethnic minorities (including five directed to national minorities), whereas two were of a more general character (The Nordic Art Review and Swedish Book Review). The subsidy amounts granted to most of the 23 publications amounted to between 2,700 and $5,500 € . .^{22}$

As regards the funds distributed by the National Integration Office, 45 associations received Organisation Subsidies for a total amount of approximately 1.3 million $€$ in 2002, whereas 32 organisations were granted Activity Subsidies for a total of approximately $763,000 € .{ }^{23}$ It is, however, important to bear in mind that the associations use the allocated funds for many different purposes and that the available data do not contain any indication as to what portion of the subsidies is actually used for media production.

\section{Minority Radio}

Two main actors operate in the domain of minority radio: Community Radio (CR), produced and sent by over 200 immigrant associations, and the public service broadcaster SR.

Immigrant associations have been and are, together with religious and political organisations, among the most active CR broadcasters (Hadenius \& Weibull 1999: 178 \& 264; Närradion ... 2002: 72 ). The 228 immigrant associations holding a concession in 2001 constituted almost $20 \%$ of the total of 1,169 CR broadcasters registered that year (Närradion... 2002: 23, 27 \& 73). According to my inventory, ethnic groups broadcast programmes in 
17 minority languages, Swedish and English. The languages in which most programmes are sent include Persian (44), Spanish (37), Kurdish (22), Finnish (12), and Bosnian (9). As in the case of the minority periodicals, there seems to be a direct relationship between the size of the ethnic groups and the number of programmes, although one could expect a larger number of programmes in Finnish.
Although CR is a relatively cheap broadcasting form, the costs for individual associations may be considerable, and financing constitutes a central problem for many of them, especially the minor ones. Due to the limited geographical reach of the stations and the small audience size, advertising income is low and the associations are thrown upon their own idealistic work (Hadenius \& Weibull

Table 2. Overview of the Print and Broadcast Minority Media Produced in Sweden in 2002

\section{Minority Periodicals}

181 titles in minority languages, Swedish and English,

of which 40 publications are available in two or more languages,

of which 25 publications are available in one minority language and Swedish

\begin{tabular}{|c|c|}
\hline Number of titles & Language \\
\hline 38 & Finnish \\
\hline 16 & Arabic \\
\hline \multirow[t]{3}{*}{14 each } & Kurdish \\
\hline & Persian \\
\hline & Spanish \\
\hline \multirow[t]{2}{*}{7 each } & Estonian \\
\hline & Turkish \\
\hline 5 & Polish \\
\hline 4 & Bosnian \\
\hline 3 each & Aramaic, Greek, Serbian and Serbo-Croatian \\
\hline 2 each & Bengali, Croatian, Danish, German, Hungarian, Icelandic and Romanian \\
\hline 1 each & $\begin{array}{l}\text { Baluchi, Bangla, Italian, Korean, Macedonian, Meänkieli, Norwegian, Portuguese, } \\
\text { Romany chib, Russian, Sami, Slovenian, Somalian, Swedish-Finnish, Urdu, Urofarsi } \\
\text { and Yiddish }\end{array}$ \\
\hline $\begin{array}{r}---- \\
57\end{array}$ & $\begin{array}{l}\text { Swedish } \\
27 \text { of the } 57 \text { titles are in Swedish and one or more other languages, the most } \\
\text { commonly appearing being Arabic, English, Aramaic, Turkish and Spanish }\end{array}$ \\
\hline 10 & $\begin{array}{l}\text { English } \\
7 \text { of the } 10 \text { titles are in English and one or more other languages }\end{array}$ \\
\hline
\end{tabular}

\section{Minority Radio}

Community Radio

217 immigrant associations had a concession in June 2002

Data on the language of some 50 broadcasts were unavailable

\begin{tabular}{clcl}
$\begin{array}{c}\text { Number of progr. } \\
44\end{array}$ & $\begin{array}{l}\text { Language } \\
\text { Persian }\end{array}$ & $\begin{array}{c}\text { Number of progr. } \\
2 \text { each }\end{array}$ & $\begin{array}{l}\text { Language } \\
\text { Arabic }\end{array}$ \\
37 & Spanish & & Aramaic \\
22 & Kurdish & & Macedonian \\
12 & Finnish & 1 each & Croatian \\
9 & Bosnian & English \\
7 & Tigrinya & Greek \\
5 & Swedish & Somalian \\
4 & Azerbaijani & \\
3 each & Amharic & \\
& Portuguese & \\
& Serbian & \\
& Turkish & \\
\hline
\end{tabular}

Public Service

\begin{tabular}{ll}
\multicolumn{2}{c}{$\begin{array}{c}\text { Produces and/or } \\
\text { programmes }\end{array}$} \\
in
\end{tabular}


Table 2. Cont.

\begin{tabular}{|c|c|c|c|}
\hline \multicolumn{2}{|c|}{$\begin{array}{l}\text { Public Access } \\
\text { Broadcasters }\end{array}$} & $\begin{array}{l}\text { Commercial Local } \\
\text { Broadcasters }\end{array}$ & $\begin{array}{l}\text { Public Service } \\
\text { Broadcaster }\end{array}$ \\
\hline \multicolumn{2}{|c|}{ Öppna Kanalen i Göteborg } & DTU7 & The Finnish Unit \\
\hline No. of progr. & Languages & Languages & Mediemagasinet $^{1}$ \\
\hline 2 & Finnish & Albanian & The Mosaik Unit ${ }^{2}$ \\
\hline 2 & Persian & Arabic & \\
\hline 1 & Kurdish & $\begin{array}{l}\text { Bosnian } \\
\text { Persian }\end{array}$ & The Sami Unit \\
\hline \multicolumn{2}{|c|}{ Öppna Kanalen i Stockholm } & Polish & \\
\hline No. of progr. & Language & $\begin{array}{l}\text { Romanian } \\
\text { Serbian }\end{array}$ & \\
\hline 5 & Somalian & Swedish & \\
\hline 3 & Tigrinya & Turkish & \\
\hline 2 & Spanish & & \\
\hline 1 & Arabic & Commercial Producers & \\
\hline 1 & Kurdish & ISB MovieProduction AB & \\
\hline 1 & Persian & (Miniatyr) & \\
\hline
\end{tabular}

\footnotetext{
1. This programme scrutinises the media in general and often brings up issues such as the under-representation of minorities in the mainstream media workforce and the representation of immigrants in mainstream media coverage.

2. The unit was closed at the end of 2002.
}

1999: 263-5). The associations' financial resources come mainly from member fees. Subsidies granted by municipalities and counties, advertising and sponsoring constitute, on the whole, minor sources of income. There are, however, great differences between the associations broadcasting CR. In spite of the difficult economic situation many organisations face, the conclusion of the Radio and TV Authority is that state subsidies should not be implemented (Närradio... 2002: 8, 28 \& 32).

Commercial local radio has not been a realistic alternative for many small and mid-sized associations until recently as the concession fees, which were auctioned, could be rather high (between approximately 2,900 and $370,000 €$ per year). According to new regulations implemented in 2001, the concessions for local commercial TV will no longer be auctioned, but will instead be granted by the Radio and TV Authority according to technological and financial criteria, forms of ownership, and amount of a given association's own and locally produced broadcast output. The new concession fees will amount to approximately 4,400 € per year (Budgetpropositionen, Prop. 2001/02: 1, p. 118; Närradio... 2002: 16). The goals of the new regulations are to support the freedom of expression and the diversity of the output, and to promote a more locally rooted local radio (Närradio... 2002: 79). In the middle range, the new regulations, together with the expected expansion of digital broadcasting, could result in a considerably changed structure of possibilities for the minority organisations. In this context it is also worth noting that the less expensive web radio is increasingly being seen as a possible solution to the economic problems of $\mathrm{CR}^{24}$

As regards digitalisation, it is only the two public service companies SR and UR (Swedish Educational Radio) that are currently involved in digital broadcasting. However, it is expected that radio will be distributed over several different technological platforms in the future, including DAB (Digital Audio Broadcasting), satellite radio and Internet/web radio. The latter is also growing as many radio stations today supplement their ordinary broadcasts with Internet broadcasts (Närradion ... 2002: 79).

Let us now turn to the second main actor in the domain of minority radio, the public service broadcaster SR. The channel P6, Radio Sweden International (which also broadcasts over the Stockholm region under the name of Radio Stockholm International), is presented in the company's web site as the international and multicultural channel of SR. The Immigrant Languages Unit (Minoritetspråksredaktionen), which is a part of P6, is described as multi-ethnic and multicultural and, while primarily intended for immigrants in Sweden, also reaches an audience abroad through webcasts. The Unit aims at helping immigrants and native Swedes understand each other better and at informing newcomers of what happens in Sweden and how this affects them. 
Programmes are in Albanian, Arabic, Aramaic, Farsi, Kurdish, Polish, Serbian/Croatian/Bosnian, Somali, Spanish, Swedish and Turkish. P6 also relays, within Sweden, many foreign radio stations in DAB. This includes news and cultural programmes in English, French, German, Greek, Spanish, Turkish, Polish and Portuguese. ${ }^{25}$ Moreover, two special units within SR produce programmes in Sami and Finnish. The public service corporations of Finland, Norway and Sweden have initiated a joint project that aims at gathering all programmes in Sami under an all-Nordic digital audio channel. ${ }^{26}$

\section{Minority Television}

Three main actors can be distinguished within the domain of minority television: the public access broadcasters, the commercial local broadcasters and commercial producers, and the public service broadcasters.

The number of appointed public access broadcasters today amounts to 26 ; these usually reach the households of one municipality. They may be sponsored, but are not allowed to broadcast advertising. Each public access channel functions as an umbrella organisation, under which a number of organisations of different kinds operate. Ten of the 26 public access channels have taken the name "Öppna Kanalen" (Open Channel) and formed a national federation of open channels. The open channels advocate a radical media ideology and some of their members are committed media activists.

To my knowledge, there is neither an overall mapping of the immigrant associations that are members of the public access channels nor an overview of the languages of the broadcasts. However, in a recently published study it is stated that immigrant associations operate most often in the public access channels broadcasting in large urban areas such as Stockholm and Gothenburg (Bakgrundsmaterial... 2002: 15). As an example it can be noted that the open channels in these two towns, which reach 340,000 and 211,000 households, respectively, broadcast in minority languages such as Amharic, Finnish, Kurdish, Persian, Somalian, Spanish and Tigrinya. ${ }^{27}$ Both channels are also actively involved in work aiming at maintaining diversity and promoting integration.

Public access programmes in minority languages deal with both current Swedish issues and matters of specific interest for each minority, and reach relatively high audience ratings within the respective groups (Bakgrundsmaterial... 2002: 15).
While most public access channels use digital technology for the production of their programmes, the analogue technology dominates when it comes to their distribution, as the Swedish cable-TV network is still poorly digitalised. Most public access channels struggle with economic problems and cannot afford employees. Their sources of income are comprised of member fees, broadcasting fees and, in some cases, sponsoring and compensation for commissioned work. They are not entitled to state subsidies and have thus far found it difficult to obtain subsidies from municipalities, counties and the European Union (Bakgrundsmaterial... 2002: 5, 18-22 \& 25-30).

Minority groups are considerably less involved in commercial local television. However, in the past few years a number of commercial actors have begun producing and distributing programming in minority languages. One of these is the DTU7 channel, launched in 2001. The channel has a licence to send over the digital terrestrial TV-network and is further distributed by several cable operators, one of which (com hem kabel tv) belongs to the major network operators. DTU7 reaches practically the entire country and airs news, sports and entertainment in seven minority languages (Albanian, Arabic, Bosnian, Persian, Polish, Romanian and Serbian). The channel rebroadcasts programming transmitted via satellite by television companies such as the Arabic channel Al Jazeera, LBC (Lebanese Broadcasting Corporation) and the Iranian channel Jaam-e-Jam. DTU7 also broadcasts Miniatyr, which is characterised as a "multicultural programme in easy Swedish" (DTU7 Channel, www.dtu7.com $20020308)$. The programme is produced by the production company ISB MovieProduction $\mathrm{AB}^{28}$ and is presented as a cultural magazine targeting an audience of "foreigners living in Sweden as well as Swedes". It contains current affairs, music, dance, theatre and items for children, and aims at "improving understanding and building a bridge between foreigners and the Swedish Society" (Miniatyr, http:// home7.swipnet.se/ 200206 16).

In addition to the programmes in minority languages gathered under the umbrella of DTU7, several cable-network operators rebroadcast programming from television companies from other countries. In many cases this kind of output also functions as minority media. As an example, it can be noted that the cable operator com hem rebroadcasts programmes from DR1 (Denmark), NRK (Norway), TV Finland, ZDF (Germany), Polonia (Poland), OPT (Russia), HRT1 (Croatia), Pink Plus 
(Serbia), Rai Uno (Italy), TVE (Spain), and TV Chile.

The public service broadcaster SVT's programming for cultural minorities totalled 321 hours (including repeats) in 2000 (Facts about SVT 2001, 2001). Newscasts, magazine and children's programmes are regularly aired in Finnish and Sami, and a number of programmes in Meänkieli (TornedalFinnish) were sent in 2000 (Sveriges Televisions Public service-uppföljning 2000, 2001: 67-8). The company, however, produces no programmes in the other minority languages. The Mosaik Unit of SVT, which operated between 1987 and 2002, had the responsibility for the programmes in Swedish aiming at representing the multicultural society. Its staff was comprised of people with varying linguistic and cultural backgrounds. The division produced several programmes, one of which, Mosaik, contained debate, reportage and documentary and covered a broad range of social, political and cultural issues from the perspective of integration. Two other programmes produced by the Mosaik Unit (Gränslöst and Cityfolk) were built on programme exchange with other European television companies within the frame of the European Broadcasting Union, EBU (Sveriges Televisions Public service-uppföljning 2000, 2001: 66-7).

In fall 2002, the management of SVT announced that the Finnish-speaking current affairs programme Ekg and Mosaik (both the programme and the Unit) would be closed. The Finnish Unit was to continue working, albeit with reduced resources, while the Mosaik Unit would be split. Staff members were exhorted to "sell their ideas" to other units within SVT. At the same time, a Mångkulturellt Centrum (Multicultural Centre) was launched by the management of SVT. ${ }^{29}$ The aim of this centre is to provide support to other units within SVT in issues related to the multicultural society.

The two main public service channels SVT1 and SVT2 are transmitted in both the analogue and the digital terrestrial networks, as well as digitally via satellite.

\section{The Views of Media Producers and Activists}

A number of minority media producers and activists gathered at a conference in Malmö in 2000. Scholars, Members of Parliament and officials of the National Integration Office, the Swedish Council for Cultural Affairs, the Swedish Press subsidies Council, the Swedish Journalist Association, the National Institute for Working Life and other cultural and media institutions also participated in the event. The conference report (Invandrar- och minoritetsmedia i Sverige... 2000) provides a useful overview of the ways in which those directly involved in the production of minority media see their situation and working conditions. Among the themes most discussed at the conference were: 1 ) misrepresentation and under-representation of minorities and their countries of origin in Swedish majority media content, 2) under-representation of minority members in the Swedish mainstream media workforce, and 3) criticism toward the current system of press subsidies.

1) According to periodical editors and scholars, the minority media have a many-fold function: as they convey information on both the homeland and the country of settlement, these media provide tools for identity reconstruction as well as integration. Several participants underlined that immigrants are "invisible" in mainstream media, whereas others noted that, when they appear, they do so as victims or criminals. Moreover, even their countries are "forgotten" in the majority media. For all these reasons, immigrants cannot recognise themselves in the mass media and live in a state of "information deficit". Minority media producers stated that through the production of their own media they attempt to provide the kind of information that helps to qualify rough generalisations, by which they also contribute to spreading knowledge that can be used in the struggle against prejudice and racism (Invandrar-och minoritetsmedia i Sverige... 2000: 16, 18$9,26,48,65 \& 67)$. One could thus say that the minority media fills a compensatory function.

2) A Swedish journalist characterised the Swedish mainstream media as "in practice ethnically cleansed" and populated by "white Anglo-Saxon protestants", with exceptions such as the Minority Language Unit of the public service SR, of which many staff members are immigrants. Another speaker underlined that the journalists working in the major media lack close contacts with immigrants, which has an influence on the quality of the coverage (Invandrar- och minoritetsmedia i Sverige... 2000: 18, 23-4 \& 42-3).

3) The current system of press subsidies was criticised for not having followed the development of the press market, and several speakers concurred that there is an urgent need for its reform in order that it better shield cultural diversity. The very principle that the conditions for obtaining the subsidy apply equally to all was questioned. It was argued, for instance, that the requirement of having a circulation of 2,000 copies in order to qualify for the subsidy is unfair, as newspapers in Swedish 
have larger potential readerships than do those in minority languages. The requirement of publishing an issue per week was criticised on similar grounds (Invandrar- och minoritetsmedia i Sverige... 2000: 20, 29, 74).

One of the results of the conference was the formation of Förbundet för invandrar- och minoritetsmedia i Sverige, FIMMS (the Swedish Federation of Immigrant and Minority Media), the goal of which is to further the interests of minority media in Sweden, work for closer contacts with the Swedish institutions, and increase the professional skills and rate of occupation among the immigrants working in the media. Since the conference, FIMMS has called on members of government and cultural institutions officials and, according to Boldt (2001: 8), played an important role in prompting the government to commission the report on immigrant and minority media in Sweden, which was completed in 2002.

Criticism of the current media policy has also come from quarters such as the National Federation of Open Channels, which in one issue of its bulletin Public Access (2002: 5, p. 1) scrutinises the report on CR (Närradion...), published in 2002 by the Swedish Radio and Television Authority, RTVV. According to the bulletin, RTVV cannot convincingly explain its refusal to recommend to the government the creation of a system of support for the CR. The article asks, for example, why the CR should be exempted from public support when public service broadcasting, newspapers and periodicals all receive state funding. This absence of support is believed to especially affect groups such as immigrants, who lack the economic resources needed to form strong organisations.

\section{Conclusions}

The most striking when examining the conditions of production of minority media and the policies that affect them is, on the one hand, the heavy reliance of these media on either the voluntary work of members of minorities, state subsidies, or the efforts of the public service broadcasters SR and SVT, and, on the other hand, their low degree of commercialisation.

In the press, most periodicals are small and depend on idealistic work, and it is unclear whether the five newspapers that today receive the press subsidy would be able to survive without it. This serves as an indication of what happens when groups that in some respects are initially less powerful than many others are forced to compete "on equal conditions" with actors in the majority soci- ety. Conditions are not equal when the starting points of the actors are so diverse.

The reliance on state support is a very problematic matter and, although I align myself with its defenders, and with an ideology of social responsibility in general, I would like to argue that one should not overlook the dangers involved in too heavy a reliance on this support. In the 1970 s, periodicals issued every second week were entitled to press subsidies for a short period of time. Today, the requirement for qualifying for the subsidy is weekly publication. This shows that subsidies come and go, as do policy orientations, governments and periods of prosperity, even in a society that, like Sweden, has long enjoyed relative stability.

The scantiness of commercial, or, for that matter, other kinds of initiatives may be due to a series of reasons. One is the size of the potential readership or audience of a medium, which in turn relates to the size of specific minority groups. For instance, few of the minorities living in Sweden surpass the number of 60,000 . Another reason may be specific policy regulations such as the limited reach of the CR stations (one municipality), which may discourage potential advertisers. A third reason is naturally the structure and history of the Swedish broadcasting system, which until two decades ago was dominated by public service companies. After all, new actors in the domain of radio and television have been operating for only 15 to 20 years. It is probable that the new digital technologies of production and distribution - together with the growing awareness of many media activists that the work they do is necessary and good not only for their groups, but also for the multicultural society as a whole, as well as their fair expectation of making a living from this work - will result in a media system with fewer unpaid enthusiasts and more variation of autonomous actors.

As regards the role and performance of the public service broadcasters SR and SVT, it can be said that there is a split between policy and practice. SR and SVT have participated in European projects (e.g., More Colour in the Media and More Diversity in the Media), which resulted in the formulation of a Cultural Diversity Policy and a Diversity Recruitment Policy. ${ }^{30}$ Media researcher Christian Christensen (2001) has fruitfully theorised on this split, noting that although programming aimed at ethnic minorities is regarded by the SVT producers and managers he interviewed as "typical public service", the survival of such output has largely been the result of strict policies and regulations rather than progressive ideologies. 
The recent cutbacks in the Finnish Unit of SVT and the closing of the Mosaik Unit can be related to what Christensen calls the schizophrenia of public service: minority and multicultural units and their programmes are hailed as part and parcel of the very raison d'être of public service, but are the most likely to suffer cutbacks were it not for regulations and quotas.

Because of its connections to the state and its historical commitment (educating the people), public service broadcasting has played a central role in processes of nation-building. The question is, according to Christensen, how public service companies, with their ties to processes of nation-building and the drawing of boundaries between "us" and "them", can cope with rapid increases in ethnic minorities.

Nonetheless, however problematic this relationship between homogenising nation-building and an adequate coverage of the multicultural society within public service broadcasting may be, it is important that we continue to demand that public service fulfil its responsibility in this regard. The reason for this is, as Charles Husband has rightly argued, that for ethnic minorities to be empowered they need both their autonomous, distinctive media and participation in mainstream media (Husband 1994: 2). It is through the latter that they can maintain a dialogue with their fellow citizens within other minorities and majority society.

Let us now turn to the domain of policy. This overview shows that Sweden lacks specific forms of support for minority media production. There is no system of state support for radio and TV in minority languages, and the three main forms of state support available to minority periodicals that I mentioned in this text are not specifically designed for minority media. Two of these forms, press subsidies and grants to arts periodicals, are aimed at all sorts of publications and, as noted above, there is something problematic in the principle that the conditions for obtaining, the press subsidy apply equally to all. The third form of support, subsidies from the National Integration Office, in turn, is not specifically designed for minority media, but for minority organisations in general. One could thus conclude that although the general cultural policy goals stated in official documents are grand, the performance of the state as regards its willingness and ability to take public responsibility for managing ethnic diversity in the domain of the media is still poor.

\section{Notes}

1. This article is a revised and updated version of the report "Mapping Minorities and Their Media: The National Context - Sweden", which I prepared within the frame of the project Minorities and their Media in the EU: A Mapping, a larger European project based at London School of Economics (Camauër 2002). The preparation of this report was made possible partly by a grant from the Department of Humanities at Örebro University. I am also grateful to the media producers and government and institution officials who provided materials and shared information with me, particularly to Lise Blomqvist, author of the report on minority media in Sweden commissioned by the Press Subsidies Council.

2. Catalogue Invandrar- och minoritetstidskrifter, National Integration Office, www.integrationsverket. se/tidskriftera.html 200204 11. A few months after the completion of my inventory, the catalogue disappeared from this site. This catalogue was in turn built on a list of periodicals compiled by Immigrantinstitutet, which is available at the site of the institute, www.immi.se/tidskrifter.

3. The list of CR concession holders was provided by RTVV (the Swedish Radio and Television Authority) official Tove De Vries and is dated 18 June 2002. It contained data on 217 concession holders. The sources on SR comprise Swedish Radio International, www.sr.se/rs/red/ind_spa.html 200206 14; Sameradio www.sr.se/sameradio.index.htm 200206-14; and Sisu Radio (www.sr.se/sisuradio 200206-14.

4. Sveriges Television, www.svt.se 200206 14; Öppna Kanalen i Stockholm, (www.openchannel.se/ stockhom.verksam.htm 200206 14; Öppna Kanalen i Göteborg, www.openchannel.se/goteborg/ starte2.htm 200206 14; DTU7, www.dtu7.com 200203 08; Miniatyr http://home7.swipnet.se/ 200206 16; and com hem kabel tv, (www.comhem. com/ 20020616.

5. “Etniska minoriteter". In Nationalencyklopedin, www.ne.se/jsp/search/article.jsp?i_art_id=320855 20020614.

6. See, e.g., the Government's Letter 2001/02: 129, Integrationspolitik för 2000-talet, p. 72.

7. “Tornedalsfinnar". In Nationalencyklopedin, www.ne.se/jsp/search/article.jsp?i_art_id=329593 20020614. 
8. "Sverigefinnar". In Nationalencykolpedin, www. ne.se/jsp/search/article.jsp?i art id=320914 2002 0614.

9. “Etniska minoriteter". In Nationalencyklopedin, www.ne.se/jsp/search/article.jsp?i_art_id=320855 20020614 and "Romer". In Nationalencyklopedin, www.ne.se/jsp/search/article.jsp?i_art_id $=29504320020614$.

10. “Judar". In Nationalencyklopedin, www.ne.se/jsp/ search/article.jsp?i_art_id=217665 20020614 .

11. In this context it is important to bear in mind that the exact extent of emigration from and immigration to Sweden is known only from 1851 onwards (Lundh \& Ohlsson, 1999/94:11).

12. Telephone communication with Ministry of Culture official Åsa Finnström 20020320.

13. The original title of the report is Minoriteternas medier. Kartläggning och analys av situationen för medier som främst riktar sig till invandrare och nationella minoriteter I Sverige (Minorities' Media. A mapping and analysis of the media mainly addressing immigrants and national minorities in Sweden; my translation).

14. Telephone communication with Ministry of Culture official Matilda Sommelius, 20030605.

15. Riktlinjer för organisations- och verksamhetsbidrag för år 2002 enligt förordningen SFS 2000: 216 (p. 1-3), document provided by National Integration Office official Jaklyn Bayru 20020408.

16. These licensing conditions are built on the guidelines approved by Parliament.

17. The Charter for Television Broadcasting Services in Sweden www.svt.se/hela/inenglish/charter.pdf 20020614.

18. The entire inventory is available in Camauër 2002.

19. Boldt (2001:4) and Invandrar-och minoritetsmedia $i$ Sverige... (2000: 6) estimate the number of minority publications at some 200 .

20. These data come from the Swedish Press Subsidies Council's web site, www.presstodsnamnden.se 2002 06 02, where the amounts are given in Swedish krona. The currency rate was $1 €=9.15$ krona 200206 11. All amounts given in the following are in accordance to this rate.

21. These data come from a list of granted press subsidies for 2002 provided by Swedish Press Subsidies Council official Kurt Hedman 200204 10. In 2002 Nyhetstidningen Sesam filed a bankruptcy petition and was taken over by another editor. The press subsidy received by the weekly in 2003 amounted to $222,000 €$.

22. These data come from a list of recipients of subsidies to "arts periodicals" for 2002 , provided by Swedish Council for Cultural Affairs official Maria Ågren 20020411.

23. These data come from a list of recipients of Organisation Subsidies and Activity Subsidies for 2002, provided by National Integration Office official Jaklyn Bayru 20020408.
24. Telephone communication with Enrico Mancini, producer of the CR station Nueva Radio Internacional, 20020619.

25. Radio Sweden International, www.sr.se/rs/red/ ind_spa.html 20020614.

26. Sameradio, www.sr.se/sameradio.index.htm 200206 14.

27. Öppna Kanalen i Stockholm, www.openchannel.se/ stockholm/verksam.htm and Öppna Kanalen $i$ Göteborg, www.openchannel.se/goteborg/starte2. htm 20020615.

28. The company is owned by three Iranian brothers and owns $20 \%$ of DTU7.

29. See Journalisten (the Swedish Journalists Union's periodical), www.journalisten.nu/a.asp?article_id= 4436200306 08, and Mosaik, www.svt.se/mosaik/ reportage.asp? $\mathrm{S}=2853 \& \mathrm{~A}=285320030608$.

30 . For an account of these policies, see the Multicultural Skyscraper, www.multicultural.net/research results.htm

\section{References}

Bakgrundsmaterial och redovisning från lokal-TV hearingen (2002). Hanninge: Radio- och TV-verket (pdf-document available at www.rtvv.se).

Befolkningsstatistik 2000, del 3 (2001) Stockholm: Statistiska Centralbyrån [Statistics Sweden].

Boldt, Jolin (2001) European minority medias. Paper presented at the European Multicultural Media Conference, Turku, October $14^{\text {th }} 2001$.

Budgetpropositionen, Prop. 2001/02: 1 [Budget Proposals. Government Bill 2001/02:1].

Camauër, Leonor (2002) Mapping Minorities and Their Media: The National Context -Sweden. Report prepared within the frame of the project Minorities and their Media in the EU: A Mapping. London: London School of Economics. http://www.lse.ac. uk/Depts/Media/EMTEL/Minorities/minorities. html

The Charter for Television Broadcasting Services in Sweden, www.svt.se/hela/inenglish/charter.pdf

Christensen, Christian (2001) Minorities, Multiculturalism and Theories of Public Service, in Kivikuru, Ullamaija (red.) Contesting the Frontiers: Media and Dimensions of Identity. Göteborg: Nordicom.

DTU7 Channel, www.dtu7.com 2002-03-08.

Daun, Åke (1992) Introduction. In Åke Daun, Billy Ehn \& Barbro Klein (eds.), To Make the World Safe for Diversity: Towards an Understanding of MultiCultural Societies. Tumba: The Swedish Immigration Institute and Museum.

Etniska minoriteter. In Nationalencyklopedin, www.ne. se/jsp/search/article.jsp?i_art_id=320855 2002-0614.

Facts about SVT 2001 (2001), www.svt.se/svtinfo/ inenglish/svtfacts00-01.pdf 
Frachon, C. \& Vargaftig, M. (eds.) (1995) European Television: Immigrants and Ethnic Minorities. London: John Libbey.

Georgiou, Myria (2002) "Mapping Minorities and their Media: The National Context - The UK Report". Report prepared within the frame of the project Minorities and their Media in the EU: A Mapping. London: London School of Economics. http:// www.1se.ac.uk/Depts/Media/EMTEL/Minorities/ minorities.html

Hadenius, Stig \& Weibull, Lennart (1999) Massmedier. Press, radio \& TV i förvandling. Stockholm: Albert Bonniers Förlag.

Hammar, Tomas (1992) A Crisis in Swedish Refugee Policy, in Daun, Åke; Ehn, Billy \& Klein, Barbro (eds.) To Make the World Safe for Diversity: Towards an Understanding of Multi-Cultural Societies. Tumba: The Swedish Immigration Institute and Museum.

Hultén, Gunilla (2001) 50 år med främlingen, In Lindblom Hulthén, Agneta (ed.) Journalisternas bok 1901-2001. Stockholm: Svenska Journalistförbundet.

Husband, Charles (2000) Media and the Public Sphere in Multi-ethnic Societies, in Cottle, Simon (ed.) Ethnic Minorities and the Media. Buckingham: Philadelphia: Open University Press.

Husband, Charles (ed.) (1994) A Richer Vision: The Development of Ethnic Minority Media in Western Democracies. London: John Libbey.

Immigrants in Sweden (1999) Stockholm: The Swedish Institute.

Integrationspolitik för 2000-talet (2002) Regeringens skrivelse 2001/02: 129 [The Government's Letter 2001/02: 129].

Invandrar-och minoritetsmedia i Sverige. Rikskonferensrapport 2000 (2000). Lund: Africa Forum Publications Afp.

Invandrar- och minoritetstidskrifter www.integrationsverket. se/tidskriftera.html 2002-06-15.

Journalisten, www.journalisten.nu/a.asp?article_id $=4436$ 2003-06-08.

Judar, in Nationalencyklopedin, www.ne.se/jsp/search/ article.jsp?i art id=217665 2002-06-14.

Lundh, Christer \& Ohlsson, Rolf (1999/94) Från arbetskraftsimport till flyktinginvandring. Stockholm: SNS Förlag.

Mass Media (1999). Stockholm: The Swedish Institute.

Miniatyr, http://home7.swipnet.se/ 2002-06-16.

Minoriteternas medier. Kartläggning och analys av situationen för medier som främst riktar sig till invandrare och nationella minoriteter I Sverige (2002). Stockholm: Presstödsnämnden.

Mosaik, www.svt.se/mosaik/reportage.asp?S=2853\&A= 2853 2003-06-08.

Naficy, Hamid (1993) The Making of Exile Cultures: Iranian Television in Los Angeles. Minneapolis: University of Minnesota Press.

Naficy, Hamid (1999) "Introduction: Framing Exile from Homeland to Homepage". In Hamid Naficy (red.) Home, Exile, Homeland: Film, Media, and the Politics of Place. London: Routledge.

Närradion - igår, idag och imorgon (2002). Haninge: Radio- och TV-verket.

Radio Sweden International www.sr.se/rs/red/ind spa.html 2002-06-14

Rapport Integration 2001 (2001). The National Integration Office. www.integrationsverket.se/rapporter/ arsboken.html 20020411.

"Romer". In Nationalencyklopedin, www.ne.se/jsp/ search/article.jsp?i_art_id=295043 2002-06-14.

Runblom, Harald (1990) Brytpunkter, Invandrare och minoriteter 5-6/1990.

Sameradio www.sr.se/sameradio.index.htm 2002-06-14.

The Sami People in Sweden (1999). Stockholm: The Swedish Institute.

Sveriges Televisions Public service-uppföljning 2000 (2001). Stockholm: Sveriges Television.

Statute of Annual Press Subsidies, SFS 1996: 1607. Stockholm: Ministry of Culture.

Svanberg, Ingvar \& Tydén, Mattias (1992) Tusen år av invandring. Stockholm: Gidlunds.

Sverige, framtiden och mångfalden - från invandrarpolitik till integrationspolitik, Prop. 1997/98: 16 [Sweden, the Future and Diversity - From Immigrants Policy to Integration Policy. Government Bill 1997/98: 16].

Sverigefinnar, in Nationalencykolpedin, www.ne.se/jsp/ search/article.jsp?i_art_id=320914 2002-06-14.

Swedish Cultural Policy: A Brief Review of National Measures (1997). Stockholm: Swedish National Council for Cultural Affairs.

Swedish Cultural Policy (1998). Stockholm: The Swedish Institute.

Working Together for Diversity (undated) www. integrationsverket.se/insightny.html 20020412.

Tornedalsfinnar, in Nationalencyklopedin, www.ne.se/ jsp/search/article.jsp?i_art_id=329593 2002-0614

Weibull, Lennart \& Wadbring, Ingela (2000) De nya svenskarna möter massmedier. In Lennart Nilsson (ed.) Region $i$ omvandling. Göteborg: SOM Institutet.

Öppna Kanalen i Stockholm, www.openchannel.se/ stockholm/verksam.htm 2002-06-15.

Öppna Kanalen i Göteborg, www.openchannel.se/goteborg/starte2.htm 2002-06-15.

\section{Other sources}

Community Radio station Nueva Radio Internacional Telephone communication with Enrico Mancini, producer of the CR station Nueva Radio Internacional, 20020619.

Ministry of Culture Telephone communication with Ministry of Culture official Asa Finnström, 20020320.

National Integration Office

Katalog Invandrar- och minoritetstidskrifter, www. integrationsverket.se/tidskriftera.html 20020411. 
Riktlinjer för organisations- och verksamhetsbidrag för år 2002 enligt förordningen SFS 2000: 216, document provided by National Integration Office official Jaklyn Bayru 20020408.

List of recipients of Organisation Subsidies and Activity Subsidies for 2002, provided by National Integration Office official Jaklyn Bayru 20020408.

List of recipients of Project Subsidies for 2001, provided by National Integration Office official Jaklyn Bayru 20020613

Radio and Television Authority List of community radio concession holders for 2001 , provided by Radio and Television Authority official Tove De Vries 20020617.
Swedish Council for Cultural Affairs List of recipients of subsidies to "arts periodicals" for 2002, provided by Swedish Council for Cultural Affairs official Maria Ågren 20020411.

Swedish Press Subsidies Council

List of recipients of direct press subsidies for 2002, provided by Swedish Press Subsidies Council official Kurt Hedman 20020410.

List of web sites provided by Lise Blomqvist, head of the inquiry on immigrant and minority media in Sweden, appointed by the Swedish Press Subsidies Council (2002 06 13). 